\title{
EXCRETION OF 11-OXYCORTICOSTEROIDS IN PARAPLEGIC AND RHEUMATOID ARTHRITIC PATIENTS ${ }^{1}$
}

\author{
By PHILIP L. STAUB, JOHN W. MENTHE, SOL S. NELSON, AND HAROLD COHN \\ (From the Staten Island [Halloran] Veterans Administration Hospital, Staten Island, \\ New York)
}

(Received for publication September 12, 1949)

In recent years considerable interest has been directed to the adrenal cortex and its steroid products. Among the various physiologic effects produced by the adrenocortical hormones, their influence on bone metabolism has been extensively studied $(1,2)$.

Since paraplegic patients as well as those suffering from rheumatoid arthritis manifest extensive osteoporosis as part of their disease processes, we thought it of interest to investigate the urinary excretion of 11-oxycorticosteroids of these patients as compared with that of normal subjects.

\section{METHOD}

The subjects were all male patients and staff members of the Staten Island Veterans Administration Hospital. Three groups of subjects were studied. One group consisted of 13 paraplegic patients all of whom showed a marked degree of osteoporosis as determined by $\mathrm{X}$-ray examination. This osteoporosis was restricted to that portion of the skeleton distal to the spine lesion. The second was a group of 14 rheumatoid arthritic patients who showed varying degrees of osteoporosis. The third, a group of 13 laboratory workers and patients, served as a control. These subjects had no medical or surgical problems, and they showed no evidences of osteoporosis.

\section{1) Clinical}

All of the subjects were examined clinically, special attention being paid to musculature, skin, hair and fat distribution, abnormalities of the breasts, sclerae, nasal and aural cartilages. Also, $\mathrm{X}$-rays of the hands and feet were studied.

\section{2) Chemical}

Determinations of the excretion of 11-oxycorticosteroids were made by colorimetric assay on several 24 hour urine collections of each subject, using the method described by Talbot and co-workers (3).

1 This paper is published with the permission of the Chief Medical Director, Department of Medicine and Surgery, Veterans Administration, who assumes no responsibility for the opinions expressed or the conclusions drawn by the authors.

\section{RESULTS}

The levels of 11-oxycorticosteroids excreted in a 24 hour period by the three groups of subjects studied are presented in Table I.

TABLE I

\begin{tabular}{l|c|c|c|c}
\hline \multicolumn{1}{c|}{ Group } & $\begin{array}{c}\text { Number } \\
\text { of } \\
\text { subjects }\end{array}$ & $\begin{array}{c}\text { Number of } \\
\text { determina- } \\
\text { tions }\end{array}$ & $\begin{array}{c}\text { Mean } \\
\text { excretion }\end{array}$ & $\begin{array}{c}\text { Standard } \\
\text { error }\end{array}$ \\
\hline Normal & 13 & 32 & $0.28 \mathrm{mg}$ & \pm 0.02 \\
\hline Paraplegics & 13 & 27 & $0.63 \mathrm{mg}$. & \pm 0.04 \\
\hline $\begin{array}{c}\text { Rheumatoid } \\
\text { arthritis }\end{array}$ & 14 & 27 & $0.36 \mathrm{mg}$. & \pm 0.04 \\
\hline
\end{tabular}

\section{1) Normal Group:}

The assays on the urine collections of this group showed an average excretion of $0.28 \mathrm{mg}$. with a standard error of \pm 0.02 which is in agreement with the results of Talbot (4). None of this group displayed any apparent endocrine abnormalities. The ages ranged from 22 to 51 years, averaging 32.7 years. There was no apparent relationship between the 24 hour 11-OCS excretion and the age or weight.

\section{2) Paraplegic Group:}

A group of 13 paraplegic patients ranging in age from 21 to 40 years was studied. The average age was 28.7 years. One patient had a tuberculous paraplegia; in the others the paralysis was the result of trauma. The levels of lesions ranged from C6 to L1.

Clinical examination revealed normal skin, fat distribution and musculature above the level of the lesion, and atrophy of skin and muscles distal to the lesion. There was no palpable testicular atrophy.

Without exception X-rays of the hands of these patients showed normal bone density and structure 
while films of their feet revealed a marked degree of osteoporosis.

Reference to Table I shows a significantly elevated level of 11-OCS excretion by paraplegics. The mean excretion was $0.63 \mathrm{mg}$. with a standard error of \pm 0.04 .

Comparison of individual 11-OCS excretions with the level of the spine lesion showed no dependence of one on the other. Nor was there a correlation between the amount of 11-OCS excreted and the duration of the paraplegia.

\section{3) Rheumatoid Arthritis Group:}

This study included 14 patients with rheumatoid arthritis, 25 to 57 years old, with an average of 46 years.

Clinical examinations revealed normal hair and fat distribution, and no abnormalities of the breasts.

$\mathrm{X}$-rays of the hands and feet showed varying degrees of osteoporosis. Eleven patients had marked osteoporosis, two showed slight osteoporosis, and two had normal bone structure.

The average 11-OCS excretion for this group was $0.36 \mathrm{mg}$. with a standard error of \pm 0.04 . Elimination of the four patients with little or no osteoporosis would raise the mean excretion for the remainder of this group to $0.38 \mathrm{mg}$.

\section{DISCUSSION}

The physical and emotional stress to which the paraplegic must constantly adapt himself might be a factor leading to the increase of 11-OCS excretion according to the "adaptation concept" of Selye (5).

If the extensive osteoporosis of paraplegic patients resulted solely from the presence of increased catabolic hormones, one would expect the bony changes to be generalized rather than limited to the areas distal to the spinal cord lesion. Albright (1) names three factors which influence bone formation; $a$ ) steroid hormones, $b$ ) stresses and strains upon the bones, $c$ ) nitrogenous building blocks. It is quite conceivable that the inevitable diminution of the stresses and strains to which the involved portion of the skeleton of paraplegics is subject, might make them more susceptible to the catabolic action of the increased cortical hormones, and it is this combination of factors which may determine the site of the osteoporosis.
In so far as the group of rheumatoid arthritics is concerned, if the osteoporosis in our group of these patients was due to the action of the steroid hormones, an increased excretion of 11-OCS should be demonstrable.

The absence of any significant deviation from the normal of 11-OCS excretion in patients with rheumatoid arthritis would indicate that their osteoporosis is not related to these steroid hormones.

It is of interest to note that Hench and Kendall (6) using Compound $\mathrm{E}$ on rheumatoid arthritic patients demonstrated on elevation of the excretion of corticosteroids in their urines.

\section{SUMMARY}

1. The 24 hour excretion of $11-O C S$ was significantly elevated in a group of 13 paraplegic patients all of whom had marked osteoporosis of the bones of the lower extremities.

2. A group of 15 patients with rheumatoid arthritis was similarly studied and although the range of the 24 hour excretion was wide and somewhat elevated, there was no statistically significant abnormality in the output of this steroid.

3. The urinary excretion of $11-\mathrm{OCS}$ in a group of 13 normal subjects was studied as a control.

\section{BIBLIOGRAPHY}

1. Albright, F., Osteoporosis. Ann. Int. Med., 1947, 27, 861.

2. Reifenstein, E. C., Jr., and Albright, F., The metabolic effects of steroid hormones in osteoporosis. J. Clin. Invest., 1947, 26, 24.

3. Talbot, N. B., Saltzman, A. H., Wixom, R. L., and Wolfe, J. K., The colorimetric assay of urinary corticosteroid-like substances. J. Biol. Chem., 1945, 160, 535.

4. Talbot, N. B., Albright, F., Saltzman, A. H., Zygmuntowicz, A., and Wixom, R., The excretion of 11oxycorticosteroid-like substances by normal and abnormal subjects. J. Clin. Endocrinol., 1947, 7, 331.

5. Selye, H., General adaptation syndrome and diseases of adaptation. J. Clin. Endocrinol., 1946, 6, 117.

6. Hench, P. S., Kendall, E. C., Slocumb, C. H., and Polley, H. F., The effect of a hormone of the adrenal cortex (17-hydroxy-11-dehydrocorticosterone: Compound E) and of pituitary adrenocorticotropic hormone on rheumatoid arthritis; preliminary report. Proc. Staff Meetings of the Mayo Clinic, 1949, 24, 181. 